\title{
Immunological parameters in periparturient sheep
}

\author{
N. Lacetera ${ }^{1}$, U. Bernabucci, A. Nardone and B. Ronchi
}

Dipartimento di Produzioni Animali, Università degli Studi della Tuscia, Viterbo, Italy

\begin{abstract}
Two experiments were carried out to assess immunological parameters in periparturient dairy sheep. The Experiment 1 pointed out that cell-mediated immune response before lambing is weaker $(\mathrm{P}-<-0.001)$ in first-parity compared to pluriparous ewes. The same study also revealed that preweaning mortality and other related parameters, and serum immunoglobulins in post-colostral lambs did not differ between lambs born to primiparous or pluriparous ewes. Experiment 2 demonstrated that cell mediated immune response in periparturient Sardianian ewes is suppressed $(\mathrm{P}-<-0.01)$ during the last week before and first week after lambing
\end{abstract}

KEY WORDS: sheep, immune response, parity, periparturient period

\section{INTRODUCTION}

A series of studies carried out in bovines demonstrated that immune response is affected by parity (Soper et al., 1978; Gilbert et al., 1993), and that the periparturient period is critical to immunity and health (Kehrli et al., 1989).

No published data have been found on the relationships between parity and immunoresponsiveness in sheep, or on the immunoresponsiveness of healthy nontketotic sheep during the transition period.

A previous study demonstrated that subclinical pregnancy toxaemia in late pregnant sheep was associated with immunosuppression, and that concentration of plasma non esterified fatty acids (NEFA) and $\beta$-hydroxy-butyrate (BHBA) were negatively correlated with immune responses (Lacetera et al., 2001).

The two studies reported here were carried out to assess immunological parameters in dairy sheep around lambing. Experiment 1 was carried out to assess whether parity affects cell--mediated immunity of late pregnant sheep, preweaning mortality or passive immunization of lambs; Experiment 2 was carried out to monitor the immune response of sheep during the entire transition period.

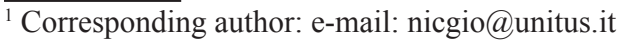




\section{MATERIAL AND METHODS}

\section{Experiment 1}

This study was carried out on eight Sardinian sheep farms in the temperate territory of Tuscia (central-west Italy) in the period October-December 2001. In each farm, 70 pregnant sheep ( 35 primiparous and 35 pluriparous) were selected for the study on pre-weaning mortality and passive immunization. Pre-weaning mortality of lambs born from the 560 sheep was recorded by asking the operators to adopt and maintain a common lamb record system. A total of 745 lambs were monitored.

Ten days before the expected lambing, blood samples were taken from 16 of the 70 sheep (eight primiparous and eight pluriparous)/farm to determine plasma concentrations of glucose, NEFA, and BHBA, and to establish the DNA synthesis capacity of peripheral blood mononuclear cells (PBMC) stimulated with concanavalin A (ConA, $2.5 \mu \mathrm{g} / \mathrm{ml})$ or pokeweed mitogen $(0.4 \mu \mathrm{g} / \mathrm{ml})$. The DNA synthesis was quantified by an ELISA, and data were expressed as the optical density. A total of 128 sheep were monitored.

One week after birth, all lambs born from the 16 sheep selected in each of the 8 farms were bled and serum immunoglobulin (Ig) $\mathrm{G}$ was determined by radial immunodiffusion. A total of 165 lambs were monitored.

\section{Experiment 2}

Experiment 2 was carried out in the period October 2003 to January 2004 in a Sardinian sheep farm located in the same territory as Experiment 1. On days 28, 14 and 3 before, and 4, 10, 17, 25, 31 and 38 after lambing PBMC were isolated from fifteen pluriparous ewes and stimulated with ConA $(2.5 \mu \mathrm{g} / \mathrm{ml})$ to establish (see Experiment 1) their capacity to synthesise DNA.

\section{Statistical analysis}

Data referred to plasma concentrations of glucose, NEFA and BHBA, DNA synthesis capacity of PBMC, and serum IgG were analysed by using a repeated measures procedure (Instat, GraphPad Software Inc, USA).

Values were expressed as Lsmeans \pm SEM, and effects were considered to be significant at $\mathrm{P}<0.05$.

\section{RESULTS}

\section{Experiment 1}

None of the parameters referring to mortality of lambs differed significantly between first-parity and pluriparous ewes. Among parameters taken into consideration, farm effect was significant only for mean pre-weaning mortality rate. 
Mean mortality rate in each unit was $5.8 \pm 5.1 \%$ (ranging from 0 to $14.4 \%$ ) with a very high coefficient of variation (88\%). Average age at time of death was $6.8 \pm 5.1$ days. Lambs born as twins or singletons accounted for 54.1 and $43.7 \%$ of total losses, respectively (2.2\% not reported). Finally, losses were equally distributed between males (48.7\%) and females (49.9\%) (1.4\% not reported).

Plasma concentrations of glucose, NEFA and BHBA did not differ between first-parity and pluriparous sheep and indicated that sheep were not suffering from ketotis or less severe forms of energy deficit. No relationships were found among these parameters and those related to lamb mortality or cellular immune response. Response of PBMC to mitogens was weaker $(\mathrm{P}<0.001)$ in first parity if compared to pluriparous ewes (Table 1).

Table 1. Least square means \pm SEM of DNA synthesis (optical density) in peripheral blood mononuclear cells of first-parity and pluriparous ewes

\begin{tabular}{lccc}
\hline & \multicolumn{3}{c}{ Mitogens $^{1}$} \\
\cline { 2 - 4 } & Ns & ConA & PWM \\
\hline First- parity & $0.11 \pm 0.13$ & $1.65 \pm 0.44^{\mathrm{a}}$ & $1.38 \pm 1.01^{\mathrm{a}}$ \\
Pluriparous & $0.12 \pm 0.15$ & $2.98 \pm 0.86^{\mathrm{b}}$ & $2.53 \pm 1.17^{\mathrm{b}}$ \\
\hline
\end{tabular}

${ }^{1} \mathrm{Ns}=$ not stimulated; ConA = stimulated with concanavalin A; PWM = stimulated with pokeweed mitogen

a,b columns with different letters differ significantly $(\mathrm{P}<0.001)$

No significant differences were pointed for $\operatorname{IgG}$ detected in serum of lambs born to first-parity or pluriparous ewes (not shown).

\section{Experiment 2}

This study demonstrated that response of PBMC to ConA changes during transition period. In particular, three days before and four days after lambing, the DNA synthesis of PBMC stimulated with ConA was lower $(\mathrm{P}<0.01)$ than that recorded four weeks before and after lambing (Figure 1).

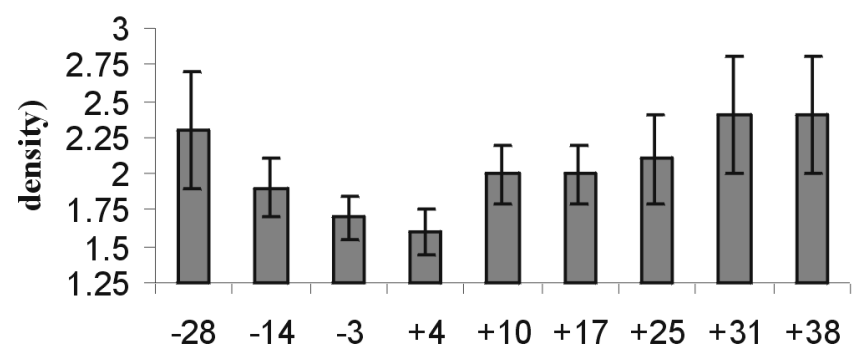

Days from lambing

Figure 1. Least square means \pm SEM of DNA synthesis (optical density) in peripheral blood mononuclear cells; ${ }^{\mathrm{a}, \mathrm{b}}$ columns with different letters differ significantly $(\mathrm{P}<0.01)$ 


\section{DISCUSSION}

Data on pre-weaning mortality do not differ from those found in a larger scale survey carried out in the same territory (Lacetera et al., 2000).

Results on relationships between parity and cellular immunity, and those on periparturient immunosuppression are novel, but in line with those referring to dairy cows (Soper et al., 1978; Kehrli et al., 1989; Gilbert et al., 1993).

\section{CONCLUSIONS}

Further studies are encouraged to establish in particular whether periparturient immunodepression is associated with alterations of other defensive mechanisms or with a higher incidence of infections.

\section{REFERENCES}

Gilbert R.O., Grohn Y.T., Miller P.M., Hoffman D.J., 1993. Effect of parity on periparturient neutrophil function in dairy cows. Vet. Immunol. Immunopathol. 36, 75-82

Kehrli M.E., Nonnecke B.J., Roth J.A., 1989. Alterations in bovine lymphocyte function during the periparturient period. Amer. J. Vet. Res. 50, 215-220

Lacetera N., Ronchi B., Bernabucci U., Scalia D., Nardone A., 2000. Rate and causes of preweaning mortality in Sardinian lambs. In: M.D. Salman, P.S. Morley, R. Ruch-Gallie (Editors). Proceedings of the $9^{\text {th }}$ Symposium of the International Society for Veterinary Epidemiology and Economics. Breckenridge, CO, pp. 1335

Lacetera N., Bernabucci U., Ronchi B., Nardone A., 2001. Effects of subclinical pregnancy toxaemia on immune responses in sheep. Amer. J. Vet. Res. 62, 1020-1024

Soper F., Muscoplat C.C., Johnson D.W., 1978. In vitro stimulation of bovine peripheral blood lymphocytes: analysis of variation of lymphocyte blastogenic response in normal dairy cattle. Amer. J. Vet. Res. 39, 1039-1042 